Eleonóra Zvalená

Univerzita v Novom Sade

Filozofická fakulta

Oddelenie slovakistiky

eleonora.zvalena@ff.uns.ac.rs
УДК 811.162.4:371(497.113)

https://doi.org/10.18485/slavistika.2021.25.2.14

Стручни рад

примљено 30.6.2021.

прихваћено за штампу 6.10.2021.

\title{
TVORIVÉ PÍSANIE VO VYUČOVANÍ SLOVENČINY AKO MATERINSKÉHO JAZYKA NA UNIVERZITE V NOVOM SADE
}

Ciel'om tohto príspevku je predstavit' možnosti využitia tvorivého písania pri rozvíjaní jazykového prejavu a jazykovej kultúry študentov Filozofickej fakulty Univerzity v Novom Sade, pre ktorých je slovenčina materinským jazykom. Študenti majú možnost' študovat' slovenčinu ako materinský jazyk v študijnom programe slovenský jazyk a literatúra alebo ako povinne volitel'ný predmet $v$ rámci štúdia iného študijného programu. Príspevok je zameraný na edukačný rozmer tvorivého písania a na jeho interakciu s oblast'ou komunikácie a jazykovej kultúry vo vysokoškolskom prostredí.

Klúčové slová: tvorivé písanie, techniky tvorivého písania, slovenčina ako materinský jazyk, jazykový prejav, jazyková kultúra, súčasný slovenský jazyk

The aim of this paper is to present the possibilities of using creative writing in the development of language expression and language culture of students of the Faculty of Arts of the University of Novi Sad whose mother tongue is Slovak. Students have the opportunity to study Slovak as a mother tongue in the study program Slovak Language and Literature or as a required elective course within the study of another study program (e.g. Serbian philology in contact with Slovak philology, German studies). The paper focuses on the educational dimension of creative writing and its interaction with the field of communication and language culture in a university environment

Keywords: creative writing, creative writing techniques, Slovak as a mother tongue, language expression, language culture, contemporary Slovak language.

Napriek tomu, že termín tvorivé písanie sa bežne používa v metodických a didaktických materiáloch a v didaktickej praxi, jeho obsah nie je jednoznačne definovaný. Pri výklade tohto pojmu sa stretneme s množstvom definícií a ich variácií, ktoré vypovedajú o jeho viacrozmernosti, i ked', samozrejme, nemožno akékol'vek písomné precvičovanie jazyka nazývat tvorivým písaním. Naším zámerom nie je kompletizovat' a sumarizovat' túto rozsiahlu problematiku, ale uchopit' tvorivé písanie ako čiastkový metodický postup, ktorý možno implementovat' do výučby konkrétnych predmetov v rámci študijných programov na Filozofickej fakulte Univerzity v Novom Sade, kde sa slovenčina vyučuje ako materinský jazyk. Pri využívaní techník tvorivého písania vychádzame z našich dlhoročných pedagogických a lektorských skúseností s výučbou slovenčiny.

Pre naše potreby vyberáme definíciu V. Eliášovej (2006: 51), ktorá hovorí, že tvorivé písanie je ,súbor motivačne prít’ažlivých činností, ktoré vyžadujú zapojit' do riešenia úloh celú osobnost' učiaceho sa, využit' jeho skúsenosti, uplatnit' jeho intelektuálne schopnosti, obrazotvornost', pozornost' aj emocionálne vlohy, a tak podnecujú učiaceho sa k skúmaniu vlastných tvorivých možností, k sebavyjadreniu a se- 
bareflexii.“ Podl’a tej istej autorky tvorivé písanie (2007: 127) „kolíše od techník napomáhajúcich tvorivú manipuláciu s jazykovým materiálom... až po techniky, ktoré umožňujú pestovat' kritickú recepciu a interpretáciu umeleckej literatúry“. Tieto techniky možno potom rozdelit' na: a) asociatívne techniky, ktoré podporujú myšlienkovú a emocionálnu stimuláciu (clustering, automatické písanie), b) techniky, ked' sa písanie stáva hrou (nonsensová poézia, poskladaný príbeh), c) usmerňované písanie podl'a predlôh a vzorov (cinquain, haiku) d) techniky, ked' je základným impulzom literárny text, ktorý sa následne upravuje (redukcia textu, transformácia žán$\mathrm{ru}, 3 \mathrm{D}$ techniky).

Spisovatel' a priekopník tvorivého písania na Slovensku Daniel Hevier posúva jeho parametre „za alebo nad samotnú zručnost' vytvárat' písaný text“ (2006: 86). $\mathrm{V}$ podstate ide o to, že výpoved'ou o svete cez introspektívny pohl'ad do svojho vnútra si každý pisatel' vytvára svoj individuálny štýl, ktorý je jedným z dôležitých ciel’ov tvorivého písania. Výhodou tvorivého písania je okrem iného aj to, že tu nejde o kvalitnú tvorivú produkciu vo vlastnom zmysle slova, a tak vymedzenie výsledných produktov/komunikátov na osi dobré-zlé/kvalitné-nekvalitné nie je určujúcim činitel'om písania. Hlavným zámerom je kultivácia písania, počúvanie samého seba a eliminácia obáv z tvorby textov. V procese tvorby autor citlivejšie vníma význam slov, slovných spojení, metafor, symbolov a obrazného jazyka.

Podla Ambrozyho tvorivé písanie „prináša v každom prípade využitie možnosti kontinuálneho alebo cyklického vylepšovania autorových tvorivých dispozícii“ (2015: 1).

V. Eliášová (2017: 20) hodnotí tvorivé písanie ako multifunkčný fenomén, ktorý je cestou ku kultivovaniu jazykového prejavu, nástrojom integrovaného vzdelávania a prostriedkom sebarozvoja. $\mathrm{Na}$ akademickej pôde sa prikláňame $\mathrm{k}$ takémuto ponímaniu tvorivého písania, pričom primárne pre nás bude vnímanie tvorivého písania ako prostriedku kultivácie jazykového prejavu, čo je aj ciel'om volitel'ných predmetov, ktoré vyučujeme a v ktorých realizujeme techniky tvorivého písania.

Ked’že písanie sa považuje za jednu z individuálnych kompetencií v osobnostnom rozvoji, v školskom systéme sa do istej miery preferuje jeho systematickost' na základných a stredných školách, a to hlavne na hodinách slohu, didaktika ktorého je dobre rozpracovaná. Avšak v celkovej koncepcii vyučovania jazyka a literatúry na základných a stredných školách nie sú tieto techniky predpísanou a povinnou aktivitou, ich používanie je v kompetencii pedagóga, ktorý sa rozhodne, či ich bude používat' a v akom rozsahu. Mnoho učitel'ov sa o tieto techniky zaujíma, avšak stále je to na báze dobrovol'nosti.

Špecifická situácia je na vysokých školách a univerzitách, kde sa študenti špecializujú na štúdium odboru, ktorý v mnohých prípadoch nemá v prvotnom ponímaní s tvorivým písaným prejavom žiadny súvis, a tak je ciel’avedomé rozvíjanie verbálnej komunikácie, v tomto prípade hlavne v písanej podobe, opomínané ako nepotrebné.

Mnohí odborníci sa však domnievajú, že tvorivé písanie je jedným z účinných interaktívnych prostriedkov rozvíjania osobnosti a malo by byt' súčast'ou výučby. M. Grupáč považuje tvorivé písanie v akademickom priestore za „dôležitý segment výučby na vysokých školách“ (2015: 4). Uznávané autority v tejto oblasti pokladajú tvorivé písanie za klúčovú kompetenciu na vysokej škole. Tento názov nesie aj 
Zborník z medzinárodnej konferencie, ktorá sa konala v roku 2004 v Brne (Tvůrčí psaní-kličová kompetence na vysoké škole. Brno, Doplněk, 2005).

Vo svete nie je vel'a univerzít, ktoré ponúkajú tvorivé písanie ako samostatný študijný program (pozri Haslinger 2009; Grupač 2015; Eliášová 2017). Ich nevel'ký počet súvisí s pragmatizáciou akademického vzdelávania a prihliadaním na jeho ekonomickú hodnotu súvisiacu s návratnost'ou vloženej energie, financií, ako aj so zohl'adnením perspektívy uplatnenia sa na trhu práce.

Tvorivé písanie sa tak na vysoké školy dostáva v podobe rôznych kurzov a seminárov, ktoré organizujú prívrženci tvorivého písania alebo v podobe tvorivých stratégií používaných pedagógom v konkrétnej vyučovacej jednotke. Avšak aj kurzy a semináre tvorivého písania sa $\mathrm{v}$ študijných programoch objavujú ojedinele a nenašli odozvu v širšej akademickej obci.

Ak chceme hovorit' o tvorivom písaní vo výučbe slovenčiny ako materinského jazyka na Univerzite v Novom Sade, musíme si povedat' o jej základných špecifikách, vyplývajúcich z multietnickosti, multijazykovosti a multikultúrnosti Vojvodiny, v ktorej žije približne 25 národností a národnostných menšín ${ }^{1}$ a kde sa akceptuje šest' úradných jazykov: srbčina, mad’arčina, slovenčina, rumunčina, rusínčina a chorvátčina.

Na univerzite sa vyučuje 5 materinských jazykov, čo je pravdepodobne unikátny jav v celosvetovom meradle.

Ako materinský jazyk sa tu vyučuje aj slovenský jazyk, a to v dvoch podobách: slovenský jazyk a literatúra ako študijný program a slovenský jazyk ako materinský jazyk vo forme povinne volitel'ného predmetu pre vojvodinských Slovákov študujúcich iné študijné programy.

Akreditovaný odbor slovenský jazyk a literatúra zastrešuje Oddelenie slovakistiky. V tomto odbore sa pripravujú budúci učitelia slovenského jazyka a literatúry, čo je jeho hlavným zameraním, ale aj novinári, prekladatelia a tlmočníci, kultúrni pracovníci, ktorí nájdu uplatnenie vo vojvodinských kultúrnych inštitúciách. Študijný program pozostáva z povinných a volitel’ných predmetov, ktoré umožňujú študentovi do istej miery profilovat' sa ešte počas štúdia. Śtúdium slovenčiny zahŕňa všetky lingvistické roviny, literárnovedné disciplíny, ako aj dejiny a kultúru Slovákov žijúcich vo Vojvodine.

Slovenčinu ako materinský jazyk pod názvom slovenský jazyk/súčasný slovenský jazyk možno študovat' vo forme volitel'ného predmetu so štvorhodinovou týždennou dotáciou počas dvoch rokov v odboroch srbská filológia $v$ kontakte so slovenskou filológiou a germanistika. Hodiny sú koncipované vo forme dvojhodinovej prednášky a dvojhodinového seminára a využívajú sa na rozvíjanie jazykových kompetencií študentov slovenskej národnostnej menšiny.

Tvorivé písanie sa zatial' na Oddelení slovakistiky ani na iných odboroch univerzity neetablovalo ako samostatný študijný program, ani ako predmet niektorého edukačného programu $\mathrm{v}$ rámci vysokoškolského štúdia, takže $\mathrm{v}$ našom príspevku budeme hovorit’ o možnostiach využitia jeho techník v rámci práce na seminároch volitel'ných predmetov. Budeme sa orientovat' na didaktické aspekty tvorivého písania ako metódy aplikovatel'nej vo vyučovaní slovenčiny ako materinského jazy-

\footnotetext{
${ }^{1}$ census 2012, Statistical office of the Republic of Serbia
} 
ka. Chceme poukázat' na význam tvorivého písania pri budovaní kultúrnej jazykovej kompetencie s akcentáciou na edukáciu v rámci vysokoškolského humanitného vzdelávania. Zároveň pripomíname, že ciel’om tvorivého písania a aktivít s ním spojených nie je vychovávat' profesionálnych spisovatel'ov, ale rozvíjat' jazykovú kultúru a kreativitu v komunikácii, ktorá sa zúročí pri tvorbe textov určených pre rozličné komunikačné oblasti a situácie. „Na vysoké škole již nejde jen o vybrušování osobního stylu. Klíčové postavení ve vzdělávání studentů má zdatnost psát texty z jiného důvodu: je totiž nástrojem poznání a sabereflexe. A stane-li se psaní přirozenou metodou tvořivých myšlenkových postupů, bude $\mathrm{v}$ budoucnu použitelným médiem úspěšné profesní komunikace. Myslet s tuškou v ruce by se mělo stát samozřejností každého absolventa vysoké školy. Znalost souboru kreativních postupů použitelných v různých fázích psaní textu je oporou pro přesný popis, výklad a hodnocení získaných informací. Poznání předmětu speciálního tématu, o němž podává písemnou zprávu lékař, stavební inženýr či antropolog, se ovšem s rozvojem vědy neustále proměňuje... Student se pomocí technik tvurčího psaní naučí vyjádřit to, co chce, tak, aby mu čtenář správně rozuměl“" (Fischer 2005: 14).

V našom príspevku sa budeme zaoberat' písaním, ktoré sa orientuje na postupy podnecujúce nekonvenčnost', netradičnost' a originalitu prejavu, ktoré majú študenta priviest' $k$ zdokonaleniu jazykovej komunikačnej normy a pestovat' jeho schopnost' vytvárat' kultivovaný jazykový prejav. Zároveň chceme podotknút', že tieto aktivity predkladáme študentom prirodzene, ako súčast’ práce na seminároch, bez osobitných inštrukcií o tvorivom písaní, bez používania tohto pojmu, bez teoretizovania a poučovania, pretože chceme spontánne výtvory, uvol’nené a slobodné kreácie bez konvenčných obmedzení. To, samozrejme, kladie nároky na prípravu pedagóga, ktorá však musí ostat pred dverami učebne. Pedagóg je podnecovatel'om, je tým, ktorý vedie študentov $\mathrm{k}$ aktivite, sebavyjadreniu a neskôr k sebareflexii. Nikdy nie je tým, kto kritizuje, odrádza alebo znechucuje.

Z hl'adiska funkčnosti tvorivého písania ako cesty ku kultivovaniu jazykového prejavu je ideálnym predmetom v rámci študijného odboru slovenský jazyk a literatúra predmet jazyková kultúra, ktorý je volitel'ným predmetom vo štvrtom ročníku štúdia. Dotácia tohto predmetu je 1 plus 2 (jedna prednáška plus dvojhodinový seminár) počas jedného semestra. Náplňou tohto predmetu je kompletizácia osvojeného učiva všetkých jazykových rovín, ktorá sa odráža v sylabách: teória jazykovej kultúry, nostrifikácia slovenského jazyka, jazykové vzdelávanie, písomná a ústna komunikácia, problematika ortoepie a ortografie, masmediálna komunikácia, jazyk školskej praxe, verejná komunikácia, jazykový manažment, jazykový prejav vojvodinských Slovákov, slovenský a srbský jazyk v kontakte, problematika prekladu.

Ako sme už uviedli predtým, slovenský jazyk si môžu ako volitel’ný predmet vybrat' aj študenti iných študijných programov (srbská filológia v kontakte so slovenskou filológiou alebo germanistika), pre ktorých je slovenčina materinským jazykom. Predmet pod názvom slovenský jazyk/súčasný slovenský jazyk má dotáciu 2 prednášky plus 2 semináre týždenne v priebehu štyroch semestrov a jeho ciel'om je zdokonal'ovanie samostatnej, jazykovo korektnej ústnej a písomnej komunikácie študentov v slovenskom jazyku.

Obidva predmety (jazyková kultúra, súčasný/ slovenský jazyk) poskytujú vhodný priestor na aplikovanie techník tvorivého písania. 
V našom prístupe $\mathrm{k}$ implementácii tvorivého písania do niektorých predmetov viažucich sa na slovakistické disciplíny pristupujeme z hl'adiska našich potrieb, t. j. naším hlavným ciel’om je zdokonal'ovanie jazykovej komunikácie, poprípade upevňovanie a precvičovanie učiva nekonvenčným spôsobom. Okrem nej je to súbor d’alších ciel'ov, ktoré sú s ním prepojené: rozvoj fantázie a originality, efektívne a experimentátorské učenie sa, schopnost' vytvorit'/spracovat' text, osvojovat' si stratégie vedúce k porozumeniu problému, odbúravanie strachu z písania, pestovanie individuálneho štýlu, kultivácia hodnotových a morálnych postojov jednotlivcov, jazykový tréning vo všetkých rečových činnostiach (tu treba spomenút' reciprocitu písania a čítania).

V rámci celkovej hodinovej dotácie tvoria techniky tvorivého písania asi 30 percent práce na hodinách jazykovej kultúry a súčasného/slovenského jazyka a majú doplnkovú funkciu.

V nasledujúcej časti uvádzame niekol'ko vybraných techník tvorivého písania, ktoré sa nám osvedčili vo výučbe slovenčiny ako materinského jazyka vo vysokoškolskom štúdiu humanitného zamerania na Univerzite v Novom Sade vo výučbe slovenčiny ako materinského jazyka. Tu treba pripomenút', že študenti slovakistiky alebo iných programov, ktorí si slovenčinu volia ako materinský jazyk/jazyk národnostnej menšiny, ovládajú slovenčinu slovom a písmom na vel'mi dobrej úrovni, podl'a európskeho referenčného rámca $\mathrm{B} 2-\mathrm{C} 1$, a tak s nimi môžeme realizovat' rôzne techniky, ktoré sú aj metodicky vel'mi rozmanité. Výber techník podriad’ujeme ciel’om multifunkčnosti tvorivého písania s dominantným akcentom na rozvíjanie jazykovej kultúry. Na každom seminári po kreatívnej písomnej časti nasleduje vlastné čítanie tvorby. Okrem samotnej prezentácie výsledného produktu je táto čast' dôležitá aj preto, že rozvíja čitatel'ské zručnosti študenta a odbúrava jeho strach z verejnej prezentácie. Pre členov skupiny je to tiež príležitost' vnímat' kreativitu spolužiakov. Nezanedbatel'nou súčast'ou takto organizovaných hodín je diskusia, ktorá vyplynie zo situácie a ktorá umožňuje študentom konfrontovat' svoj svet $\mathrm{s}$ iným svetom a s iným vnímaním reality. Kreatívny text sa tak stáva prostriedkom, ktorý učí tolerancii a úcte $\mathrm{k}$ cudziemu textu, $\mathrm{k}$ inému názoru. Použité techniky tvorivého písania sme zoradili abecedne.

Cinquain je pät'veršová báseň, ktorá zhŕňa informácie v podobe stručných výrazov opisujúcich jednu tému. Študentom sme úlohu stažili tým, že témou básne musela byt' osobnost' slovenských dejín. A vznikol takýto útvar:

\section{Štúr \\ obetavý a premýšlajúci \\ vyučoval, písal \\ jazyk je prejavom národa \\ kodifikácia}

Pri technike clustering ide o zhlukovanie slov a ich prirad’ovanie ku klúčovému slovu, ktoré figuruje ako základ uprostred. Využitím individuálnych asociácií študent prirad’uje $\mathrm{k}$ hlavnému zakrúžkovanému slovu súvisiace výrazy prostredníctvom čiar, ktoré určujú súvislosti medzi jednotlivými asociáciami. Z toho dôvodu možno rozvíjat' nielen kl’účové slovo, ale aj rozvíjané slovo. Techniku možno varírovat' napríklad tak, že naznačenú schému treba doplnit', rozvíjat' iba jedným smerom a pod. Ked’že 
sa so študentmi pohybujeme predovšetkým v priestore slovenskej lingvistiky, aj pre clustering si vyberáme kl'účové slová z tohto okruhu, napríklad národný jazyk, kodifikácia, jazykový management a pod.

Dokonči príbeh. Študenti dostanú rovnaký začiatok príbehu, ktorý potom každý z nich dopíše podl'a vlastných predstáv. Táto tvorivá technika je zaujímavá tým, že študenti môžu sledovat', akými smermi sa uberá fantázia a vyjadrovanie každého z nich. Lebo napriek rovnakému úvodu vzniknú úplne odlišné príbehy. V nasledujúcom odseku uvádzame dve rozličné pokračovania textu s rovnakým začiatkom.

1. Stál som na zastávke autobusu. Bolo niečo pod nulou. Fúkal studený februárový vietor. Poletujúci sneh mi nepríjemne udieral do tváre. Netrpezlivo som vyzeral autobus. Bol som tam celkom sám. Čakám, čakám, ale autobus nevidím. Počúvam svoju oblúbenú hudbu. Zrazu vidím v dial'ke autobus. Kým som doň nastupoval, ovládol ma negatívny pocit. Kúpil som si listok a našiel som si vol'né miesto. Pomyslel som si, že kým dorazím domov, trochu si zdriemnem. Prebudil som sa, ked' sme sa priblízili k mostu. Vjednej chvíli kvôli klzkej vozovke sa autobus pošmykol a padol do vody. Všetci cestujúci začali panikárit’. Zrazu som sa prebudil v posteli a uvedomil si, že všetko bol len zlý sen.

2. Stála som na zastávke autobusu. Bolo niečo pod nulou. Fúkal studený februárový vietor. Poletujúci sneh mi nepríjemne udieral do tváre. Netrpezlivo som vyzerala autobus, lebo som sa vel'mi ponáhl'ala domov a už som sa nemohla dočkat', kedy príde. Mali sme s rodinou cestovat' $k$ starej mame a ja som meškala. Zdalo sa mi, akoby som ho vyzerala celý deň, ale ubehlo iba 20 minút. Ked' sa človek niekam ponáhl'a, tak 20 minút sa mu zdá ako celý rok. Ale nakoniec autobus dorazil a ja som stihla príst' načas domov.

Túto techniku možno varírovat' napríklad tak, že študenti dopíšu iba jadro príbehu, pričom úvod a záver je zadaný, alebo tak, že príbeh netvoria individuálne, ale každý z nich napíše tri vety a posunie príbeh kolegovi a tak to pokračuje d'alej, kým sa nevystriedajú všetci.

Technika frazeologizmy je založená na vytváraní homogénneho zmysluplného textu zo slovenských frazeologických jednotiek. Technika je náročná, lebo študent musí ovládat' jazyk na takej úrovni, aby rozumel jeho frazémam, zároveň si musí naštudovat' dostatočne vel'ký register frazém podl'a jednotlivých tematických okruhov, aby z nich mohol vytvorit' ucelený text. Nevyhnutnou pomôckou tu bude aj frazeologický slovník. Techniku možno zadat' aj ako domácu úlohu. Ako príklad uvádzame sprievodný komentár študentky, ktorým písomne okomentovala svoju prácu : Hl'adanie vhodných frazém bolo pre mňa hl'adaním ihly v kope sena. Ale dúfam, že som nimi trafila klinec po hlavičke a že sa pri hodnotení mojej práce naplní tvrdenie: Aká práca, taká pláca.

Haiku je technika, ktorá preferuje minimalizmus vo vyjadrovaní. Je to trojveršová nerýmovaná báseň s presným počtom slabík (5-7-5), v ktorej autor vyjadruje svoje dojmy a pocity z prírody, zaznamenáva krásu a prchavost' chvíle. Haiku nemá názov a nepoužíva umelecké trópy. Učí študentov narábat' so slabikami, so slovami, svojou jednoduchost'ou, precíznost'ou a dôvtipnost'ou vyjadrovania je prostriedkom na myšlienkový a jazykový tréning. Cibrí stručnost', presnost' a pragmatickost' v komunikácii. Núti uvažovat’ nad hodnotou každého zaznamenaného slova. 
Vletnom večeri

ked' zapadá slnka svit

tíchne vtáči spev.

Neznámy jazyk. Ked’že naši študenti majú aj prekladové semináre zo slovenského jazyka do srbského jazyka a naopak, metóda neznámeho jazyka ich môže pobavit', ale aj poučit'. Ide o to, že ich úlohou je preložit' text z jazyka, ktorému nerozumejú, do rodného jazyka. „Prekladatelia“ koncipujú svoj preklad na základe intuície, pocitov, ktoré v nich neznámy text asociuje, ale aj vedomostí z teórie literatúry a teórie prekladu.

\author{
E tudo que eu pensei \\ e tudo que eu falei \\ e tudo que me contaram \\ era papel.
}

E tudo que descobr

amei

datestei:

papel.

Papel quan havia em mim

e nos outros, papel

de jornal ,

de parede

de embrulho

papel de papel

papelão. $^{2}$

Je leto den̆ je krásny

je leto deň je modrý

je leto den̆ mi hovorí

tu sú kvety.

Je leto deň je zlatý

pretože

tu sú samé

kvety.

${ }^{2}$ Originál je báseň brazílskeho básnika Carlosa Drummonda de Andrade (1902 - 1987), ktorá je napísaná v portugalčine. 


Kvety sú moje milé
nie je mi smutno
kvet
tohto života
nádhera
zázrak
kvet som kvet
kvitnem.

Obálka so slovami. Študent si z obálky vytiahne určitý počet slov, z ktorých má zostavit' príbeh bud' na l'ubovol'nú alebo vopred určenú tému. Táto technika je výborným pomocníkom pri precvičovaní témy ako objektívneho štýlotvorného činitel'a a tiež pri expanzii témy.

Obrázkový príbeh je technikou, ktorá prepája obraz so slovom. Študenti majú vytvorit' príbeh podl'a predloženého obrázka. Ked’že naši študenti sú vojvodinskí Slováci, zvolili sme obraz jedného z insitných slovenských vojvodinských maliarov, pretože tematika a spôsob jej stvárnenia je im blízky. Ide o obraz Pavla Cicku Zlodej $\mathrm{z}$ roku 2000.

V̌̌etko sa deje v nejakej imaginárnej dedine, kde si všetci vel'mi pekne spolunaživajú. Každý si robí svoju robotu. Kominár čistí komín, bociany si stavajú hniezdo, l'udia v chate oddychujú a iní zasa chytajú ryby pri rieke. Zdá sa, akoby nikto nemal súvis s nikým. Ale ked's a pozrieme trochu lepšie, máme pocit, akoby tie bociany l'udi spájali. Robia im spoločnost’ pri rieke, tiež robia spoločnost’ kominárovi a hovorí sa, že ked' bociany sedia na komíne domu, tak v tej rodine sa narodí bábätko. Takže, samozrejme, že prinášajú št’astie.

Úlohu možno d'alej rozpracovat' napríklad tak, že študenti napíšu, čo sa na obrázok nezmestilo alebo porozprávat', ako bude príbeh pokračovat'.

Oživené obrazy. Túto techniku vel'mi dobre využijeme pri precvičovaní slohových postupov, resp. naračných situácií. Študentov požiadame, aby zo svojich mobilov vybrali jednu zaujímavú snímku. Ich úlohou je napísat', prečo si ju vybrali a s akým zážitkom sa im spája.

Príbeh môjho mena. Ludia sa živo zaujímajú o svoje krstné mená, sú s nimi spokojní alebo nespokojní, častokrát sa pýtajú rodičov, prečo im vybrali práve toto meno. Študentom navrhneme, aby napísali krátky príbeh histórie ich krstného mena. Po prečítaní príspevkov sa môže rozprúdit’ zaujímavá diskusia. Na záver im dáme $\mathrm{k}$ dispozícii etymologický slovník, aby si prečítali etymologický výklad svojho mena.

\section{Na záver}

Mysliet' (a dodávame aj pracovat') s tužkou v ruke (Fišer 2005) si dnes vyžaduje mnoho akademických povolaní. Tvorivé písanie zohráva dôležitú úlohu pri vytváraní a rozvíjaní jazykových kompetencií jedincov v rozličných komunikačných oblastiach a situáciách. Vyspelá a pohotová verbálna reakcia prepojená so schopnostou písat' je potrebná v práci politikov, lekárov, učitel'ov, prekladatel'ov, administratívnych pracovníkov, právnikov, zamestnancov kultúrnych inštitúcií, inžinierov atd'. V mnohých povolaniach treba 
rýchlo a pohotovo napísat' nejaký druh textu: správu, posudok, zápisnicu atd'. Tvorivé písanie učí študentov ihned' sa zorientovat' v komunikačnej situácii, rýchlo reagovat', presne a vhodne sa vyjadrovat' (s ohl'adom na komunikačnú situáciu a zámer prejavu). Preto si myslíme, že aktivity tvorivého písania sú výborným spôsobom na rozvíjanie jazykovej kultúry študentov - budúcich zamestnancov. Prikláňame sa k názoru, že tvorivé písanie je jednou z klúčcových kompetencií na vysokej škole a dodávame, že v hierarchii predmetov by mohlo mat' aspoň pozíciu volitel'ného predmetu na všetkých typoch vysokých škôl.

V našom uchopení tvorivého písania $\mathrm{v}$ akademickom prostredí a využívaní jeho techník v práci na seminároch volitel'ných predmetov nám nejde o systematický nácvik schopnosti písat', ale o osvieženie bežnej vyučovacej hodiny, o väčšiu uvol'nenost' na cvičeniach, o menej stresujúce formy precvičovania a utvrdzovania učiva, o pocit netradičnosti a niečoho nového. Ide o doplnkovú formu, ktorá si nekladie za ciel' nahradit' učivo, ale posúva hranice rozmýšl'ania a uvažovania o aktuálnej téme, prepája odborné znalosti a kreativitu. Je netradičným prostriedkom slúžiacim na preverovanie vedomostí študentov, zároveň prostriedkom individuálneho pohl'adu na svet s možnost'ou využitia vlastnej fantázie a kreatívneho rozletu. A navyše pre študentov - nastávajúcich pedagógov - je tvorivé písanie zdrojom inšpirácií a podnetov $\mathrm{v}$ ich budúcej pedagogickej praxi.

\section{Citovaná literatúra}

Ambrózy, Marián. Význam tvorivého písania v didaktike filozofie. Príspevok z Medzinárodnej interdisciplinárnej vedeckej konferencie, ktorá sa konala 10. novembra 2015 v Prešove. <https: //www.pulib.sk/web/kniznica/elpub/dokument/Husar6/subor/ Ambrozy.pdf> 02. 02. 2021.

Bieleková, Katarína, Eleonóra, Zvalená. Tvorivé písanie vo vyučovaní jazyka a slohu (pre nižšie sekudárne vzdelávanie). Prešov: Filozofická fakulta Prešovskej univerzity v Prešove, 2012.

Eliášová, Viera. Tvorivé písanie a možnosti jeho využitia $\mathrm{v}$ edukačnom procese. Bratislava: Univerzita Komenského, 2017.

Eliášová, Viera. Vymedzenie pojmu tvorivé písanie pre cudzojazyčnú výučbu. [In:] V. Eliášová (eds.) Zborník zo Sympózia o tvorivom písaní. Bratislava: Metodickopedagogické centrum Bratislavského kraja v Bratislave, 2006, s. 41-52.

Fišer, Zbyněk. „Myšlení s tuškou v ruce.“ [In:] Z. Fišer (eds.) Tvưrčí psaní - klíčová kompetence na vysoké škole. Sborník př́spěvků z mezinárodní konference uskutečněné ve dnech 21. až 23. ř́jna 2005 na Filozofické fakultě Masarykovy univerzity v Brně. Brno: Doplněk, 2005, s. 13-16.

Fišer, Zbyněk. Tvưrčí psaní. Malá učebnice technik tvůrčího psaní. Brno: Paido, 2011. Grupač, Marián. Efektívne a tvorivé písanie I. Metóda tvorivej sebareflexie, vytvárania komunikačných platforiem a literárnej kompetencie. Online. Dostupné na internete $<$ https://fhv.uniza.sk/mkd_revue/03_2015/03_2015_grupac.pdf > 02. 02. 2021.

Grupač, Marián. Efektívne a tvorivé písanie II. Metóda tvorivej sebareflexie, vytvárania komunikačných platforiem a literárnej kompetencie. Online. Dostupné na internete $<$ https://fhv.uniza.sk/mkd_revue/04_2015/04_2015_grupac.pdf >02. 02. 2021.

Haslinger, Josef. „Proč tvurčí psaní?“" Rukopis 06. Revue o psaní IV, 2009, s. 19-22.

Hevier, Daniel. Tvorivé písaNie? Áno! [In:] V Eliášová (eds.) Zborník zo Sympózia o tvorivom písaní, Bratislava: Metodicko-pedagogické centrum Bratislavského kraja v Bratislave, 2006, 84-91. 


\title{
Eleonora Zvalena
}

\author{
KREATIVNO PISANJE U NASTAVI SLOVAČKOG \\ KAO MATERNJEG JEZIKA NA UNIVERZITETU U NOVOM SADU
}

\begin{abstract}
Rezime
Rad se bavi problematikom kreativnog pisanja i korišćenjem njegovih tehnika u nastavi slovačkog kao maternjeg jezika u akademskoj sredini, konkretno na Filozofskom fakultetu Univerziteta u Novom Sadu. Tehnike kreativnog pisanja su korišćene kao dopunska forma na časovima vežbi sa ciljem razvijanja jezičkih kompetencija i individualnog stila izražavanja studenata, kao i sa ciljem uvežbavanja i utvrđivanja gradiva nekonvencionalnim načinom podržavajući pri tome originalnost i efikasnost u izražavanju. $U$ radu se navode neke od tehnika kreativnog pisanja koje su bile primenjene na vežbama iz izbornih predmeta. Uz neke upotrebljene tehnike navode se i primeri iz studentskih radova koji su nastali na ovim vežbama.

Pisanje (i kreativno pisanje) nije namenjeno isključivo ljudima izuzetnih intelektualnih sposobnosti ili budućim piscima, već je nezaobilazan deo života mnogih ljudi. Smatramo ga važnim elementom u nastavi na fakultetima prvenstveno humanističkog, ali i drugih usmerenja. Brzo i efikasno pisanje i izražavanje sastavni su deo mnogih profesija, a od sposobnosti jasnog formulisanja misli može zavisiti uspešnost mnogih studenata u budućem profesionalnom životu.

Ključne reči: kreativno pisanje, tehnike kreativnog pisanja, slovački kao maternji jezik, jezičko izražavanje, jezička kultura, savremeni slovački jezik.
\end{abstract}

